Kajian Ilmiah Mata Kuliah Umum

Volume 15 Nomor 1, September 2015

Penerbit
Pelindung dan Penasehat
Penanggung Jawab
Pemimpin Umum
Penyunting Ahli
Pemimpin Redaksi
Sekretaris Redaksi
Anggota Redaksi

Sekretariat
: Pusat MKU Universitas Negeri Yogyakarta

: Wakil Rektor I UNY

: Wawan S. Suherman

: Sunarso

: Marzuki

: Rukiyati

: Vita Fitria

: Sri Agustin Sutrisnowati, Amir Syamsudin, Syukri Fathudin Achmad Widdodo,

Benni Setiawan

: Ari Saraswati

Alamat Redaksi/Tata Usaha:
Pusat MKU UNY, Gedung LPPMP Lt.3 Sayap Timur
Kampus Karangmalang Yogyakarta
Email: mku@uny.ac.id, mku.uny@gmail.com, ruki1961@yahoo.com

HUMANIKA Kajian Ilmiah Mata Kuliah Umum menerima kiriman tulisan/artikel yang terkait dengan Mata Kuliah Umum (MKU), yang meliputi Pendidikan Agama, Pendidikan Pancasila, Pendidikan Kewarganegaraan, Ilmu Sosial Dasar, Ilmu Budaya Dasar, Ilmu Alamiah Dasar, dan Pendidikan Kependudukan dan Lingkungan Hidup, dengan ketentuan sebagai berikut:

1. Naskah dapat berupa hasil penelitian atau artikel ilmiah bebas dan belum pernah diterbitkan.

2. Naskah diketik dengan spasi satu setengah (1,5 spasi) dengan jumlah halaman 1015 halaman kuarto, diketik dengan MS Word ukuran font 12 Times New Roman.

3. Naskah memuat komponen: judul ( $<10 \mathrm{kata})$, nama penulis, alamat email, abstrak (100-150 kata), isi karangan (yang memuat pendahuluan, pembahasan, kesimpulan) dan daftar pustaka.

4. Naskah dikirim dalam bentuk print out dan soft copy.

5. Daftar pustaka ditulis secara alfabetis seperti berikut:

- Hidayat, Komaruddin. 2004. Menafsir Kehendak Tuhan. Jakarta: Serambi.

- Bagir, Haidar. 2012. "Syiah dan Kerukunan Umat". Republika. 20 Januari. 


\section{DAFTAR ISI}

Redaksi Humanika ........................................................................... i

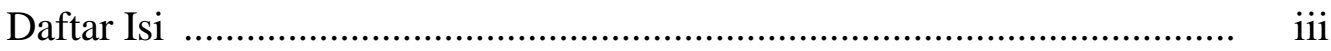

Pengantar Redaksi ...........................................................................

Islam Rahmah dan Wasathiyah

(Paradigma Keberislaman Inklusif, Toleran dan Damai)

Abd. Malik Usman........................................................................... 1-12

The Dialectics of Javanese and Islamic Cultures:

an Introduction to Kuntowijoyo's Thought

Pradana Boy ZTF

Persepsi Masyarakat Kotagede Terhadap Pengunaan Media Komunikasi oleh Organisasi Forum Joglo untuk Peletarian Budaya di Kotagede

Yogyakarta

Choirul Fajri

Implikasi Budaya Organisasi Terhadap Pola Perilaku Komunikasi

Kelompok Tani Sumber Rejeki

Mariana Ulfah dan Siti Chotijah

Etika Sosial dalam Kerukunan Umat Beragama

(Studi Kasus di Desa Kotesan Kecamatan Prambanan Kabupaten Klaten

Jawa Tengah)

Andy Dermawan dan Zunly Nadia

Model Komunikasi "Wom" Sebagai Strategi Pemasaran Efektif

Dani Fadillah

Mencari Model Pendidikan Karakter

Suparlan 


\title{
MODEL KOMUNIKASI "WOM" SEBAGAI STRATEGI PEMASARAN EFEKTIF
}

\author{
Dani Fadillah \\ danifadillah@uad.ac.id \\ Ilmu Komunikasi Universitas Ahmad Dahlan Yogyakarta
}

\begin{abstract}
ABSTRAK
Sistem komunikasi promosi adalah serangkaian komponen komunikasi yang mempunyai fungsi untuk mencapai tujuan promosi. Dalam arti yang lebih luas komunikasi dalam kegiatan promosi adalah setiap prosedur yang menyebabkan manajemen marketing dapat mempengaruhi sikap dan keputusan pelanggan atau calon pelanggan. Hal itu akan meliputi seluruh aspek perilaku manusia, termasuk ucapan yang kerap dilontarkan.Saat ini seiring dengan perkembangan teknologi banyak sekali media dan strategi yang muncul dan digunakan oleh berbagai produsen untuk mempromosikan produknya. Mereka saling bersaing untuk menciptakan teknik terjitu untuk mempersuasi konsumen agar bersedia mengonsumsi dan setia terhadap produk atau jasa yang mereka tawarkan. Namun ada sebuah strategi klasik yang sangat sulit tergantikan dalam mempromosikan sebuah produk, yaitu strategi "WOM" (word of mouth) atau strategi "mulut ke mulut". Dalam bahasa Jawa strategi ini disebut dengan nama getok tular. Keunggulan strategi model komunikasi "WOM" terletak dalam kemampuannya menyentuh unsur terdalam manusia dalam proses persuasi.
\end{abstract}

Kata Kunci : komunikasi WOM, persuasi, strategi pemasaran.

\section{PENDAHULUAN}

Memasuki era globalisasi, persaingan di berbagai bidang semakin nyata saja. Keberhasilan kinerja public relations sebagai item penting organisasi/perusahaan yang bertugas menciptakan dan mempertahankan nilai/image positif organisasi, semakin tinggi. Salah satu cara yang ditempuh adalah dengan berusaha memasarkan aktivitas public relations dengan maksimal dan efektif.

Istilah marketing public relations muncul dari adanya perbedaan pendapat para ahli public relations dengan praktisi pemasaran. Inti perbedaan terletak dalam pandangan mengenai keberadaan public relations, yaitu public relations bagian dari pemasaran atau public relations sebagai fungsi tersendiri sebagai organisasi. Perbedaan tersebut dijembatani oleh Thomas L Harris (Rhenald Kasali, 2003, hal. 12) yang mengemukakan bahwa marketing public relations (bagian pemasaran), corporate public relations (bagian korporasi).

Berdasarkan hal tersebut, pendekatan terhadap public relations dapat dilakukan melalui public relations (bagian korporasi). Pendekatan terhadap proses marketing public relations dapat dilakukan oleh public relations maupun pemasaran. Philip Kotler mengemukakan "Komunikator pemasaran harus mengambil keputusan komunikasi meliputi identifikasi audiens sasaran, menentukan tanggapan yang dikehendaki, memilih media, memilih atribut sumber dan mengumpulkan 
umpan balik" (Philip Kotler, 1987: 180). Marketing public relations merupakan bagian pengelolaan upaya komunikasi yang mempunyai tujuan membentuk citra perusahaan dan memotivasi pembelian sehingga mendorong pemilihan pendekatan public relations dengan methode of program and comunications public relations circle. Dalam bukunya The Marketer's Guide to Public Relations, Thomas L Harris mengatakan sebagai berikut.

"Marketing Public Relations is the process of planning and evaluating programs, that encourage purchase and customer through credible communication of information on impression that identify companies and their products with the needs concerns of customers".

Secara umum dapat diartikan, marketing public relations adalah suatu proses perencanaan, pelaksanaan dan pengevaluasian program-program yang dapat merangsang pembelian dan kepuasan konsumen melalui komunikasi mengenai informasi yang dapat dipercaya dan melalui kesankesan positif yang ditimbulkan dan berkaitan dengan identitas perusahaan atau produknya sesuai dengan kebutuhan, keingian dan kepentingan bagi para konsumennya. Marketing public relations adalah proses merencanakan, melaksanakan dan mengevaluasi program yang mendorong pembelian dan kepuasan pelanggan melalui komunikasi informasi dan impresi yang kredibel (Sulaksana, 2003:125).

Dari pengertian-pengertian tersebut dapat diambil kesimpulan bahwa Marketing public relations merupakan perpaduan pelaksanaan program dan strategi pemasaran (marketing strategy implementation) dengan aktivitas program kerja public relations (work program of Public relations). Dalam pelaksanaannya terdapat tiga strategi penting, yakni :

1. Pull strategy, public relations memiliki dan harus mengembangkan kekuatan untuk menarik perhatian publik.

2. Push strategy, public relations memiliki kekuatan untuk mendorong berhasilnya pemasaran.

3. Pass strategy, public relations memiliki kekuatan untuk mempengaruhi dan menciptakan opini publik yang menguntungkan.

Seperti layaknya sebuah strategi, ketiga jenis strategi ini biasanya dapat digabungkan antara satu dengan yang lain dalam upaya mendapatkan hasil yang lebih komprehensif. Penggabungan ketiga model strategi memang kerap menimbulkan risiko bagi perusahaan, karena penggabungan tiga model ini harus dengan keseimbangan antara satu dengan yang lain. Pada banyak kasus, perusahaan pasti akan lebih condong kepada salah satu jenis strategi daripada yang lain. Guna mencapai kesesuaian tersebut, perlu adanya keseimbangan dengan memberikan pengertian seimbang 
tentang strategi pull, push, dan pass dalam pemasaran.

Dalam Marketing public relations tidak ada istilah dalam pengertian sempit. Tetapi berkaitan dengan aspekaspek perluasan pengaruh, informative, persuasif, dan edukatif, baik segi perluasan pemasaran (makes a marketing) atas suatu produk atau jasa, maupun yang berkaitan dengan perluasan suatu pengaruh tertentu (makes an influence) dari suatu kekuatan lembaga atau terkait dengan citra dan identitas suatu perusahaan. Komponen-komponen dasar yang perlu diperhatikan di dalam penyusunan strategi marketing public relations antara lain produk, pasar, kekuatan (pesaing), lingkup, tujuan, sumber daya dan waktu.

\section{KOMUNIKASI \\ PEMASARAN}

DALAM

Supaya pesan promosi itu sampai dengan selamat ke penerima promosi, maka manajer marketing perlu mengenal metode komunikasi pemasaran. Pengertian metode komunikasi menurut Komaruddin Sastradipoera $\quad(2003 ; 190) \quad$ adalah "Pendekatan dan teknik komunikasi agar pesan komunikasi yang disampaikan dapat diterima dengan efektif, maka komunikasi promosi tersebut seyogyanya dilakukan melalui langkah-langkah berikut: (1) perhatian, (2) pemahaman, (3) penerimaan; dan (4) tindakan". Komaruddin pun menambahkan dalam teori komunikasi promosi dikenal paling tidak dua metode untuk masalah dan lingkungan yang berbeda, keduanya meliputi:
1. Metode Adopsi, metode adopsi bekerja dengan langkah-langkah berturut-turut meliputi : a) mengetahui akan adanya gagasan promosi, b) kian berkemmbangnya minat akan gagasan promosi, c) evaluasi atas gagasan promosi, d) mengadakan percobaan gagasan promosi, dan e) menerima gagasan promosi.

2. Metode Difusi, metode difusi bekerja dengan urutan langkahlangkah sebagai berikut: a) menetapkan orang yang dapat melakukan kontak (contact person), b) Menetapkan orang yang dapat mengestimasi (legitimizer) gagasan yang akan disampaikan kepada konsumen sasaran, c) menetapkan orang yang mempunyai kemampuan yang cukup untuk mengorganisasikannya

(organizator), dan d) menetapkan komunikator (communicator atau disseminator) yang dapat mengkomunikasikan pesan-pesan atau gagasan-gagasan promosi.

Saptaningsih Sumarmi (2008) menambahkan bahwa, "Kehadiran word-of-mouth marketing dalam mengembangkan kegiatan komunikasi dalam perusahaan tidak akan mengancam kegiatan komunikasi pemasaran lainnya, tetapi dapat dijadikan sebagai salah satu alternatif dari promotion mix sehingga menghasilkan komunikasi pemasaran yang lebih efektif dan menjual." 


\section{Pengertian Word of Mouth}

Menurut Putri (2007) yang dikemukakan oleh Saptaningsih Sumarni (2008), mengartikan "word-ofmouth seperti buzz, yaitu obrolan murni di tingkat pelanggan yang menular, tentang orang, barang atau tempat (infectious chatter; genuine, street level excitement about a hot new person, place or thing). Atau secara lebih umum obrolan tentang brand."

Sutisna $(2002 ; 184)$ berpendapat bahwa:

"Kebanyakan proses komunikasi antarmanusia adalah melalui dari mulut ke mulut. Setiap orang setiap hari berbicara dengan yang lainnya, saling tukar pikiran, saling tukar informasi, saling berkomentar dan proses komunikasi lainnya. Mungkin sebenarnya pengetahuan konsumen atas berbagai macam merek produk lebih banyak disebabkan adanya komunikasi dari mulut ke mulut. Hal tersebut sangat menguntungkan produsen yang jarang melakukan promosi dan lemah dalam mengkomunikasikan produknya dikarenakan keterbatasan biaya, sehingga sulit menjangkau konsumen lebih luas."

Berdasarkan kesimpulan diatas maka word of mouth dapat diartikan sebagai komunikasi yang dilakukan oleh konsumen yang telah melakukan pembelian dan menceritakan pengalamannya tentang produk atau jasa tersebut kepada orang lain. sehingga secara taklangsung konsumen tersebut telah melakukan promosi yang dapat menarik minat beli konsumen lain

yang mendengarkan pembicaraan tersebut.

\section{Proses Word of Mouth Communication}

Komunikasi word of mouth takdapat terjadi tanpa proses, dimulai dari sumber sampai tujuan. Setiap canelnya memiliki kepentingan yang tak boleh diabaikan, seperti pendapat Sutisna (2002). Dalam pandangan tradisional, proses komunikasi word of mouth dimulai dari informasi yang disampaikan melalui media masa, kemudian diinformasikan atau ditangkap oleh pemimpin opini yang mempunyai pengikut dan berpengaruh. Informasi yang ditangkap oleh pemimpin opini kepada pengikutnya melalui komunikasi dari mulut ke mulut. Bahkan secara lebih luas model itu juga memasukan penjaga informasi (gatekeeper) sebagai pihak yang terlibat dalam proses komunikasi tersebut. Model komunikasi word of mouth yang lebih luas digambarkan oleh Sutisna (2002;191) sebagai berikut:

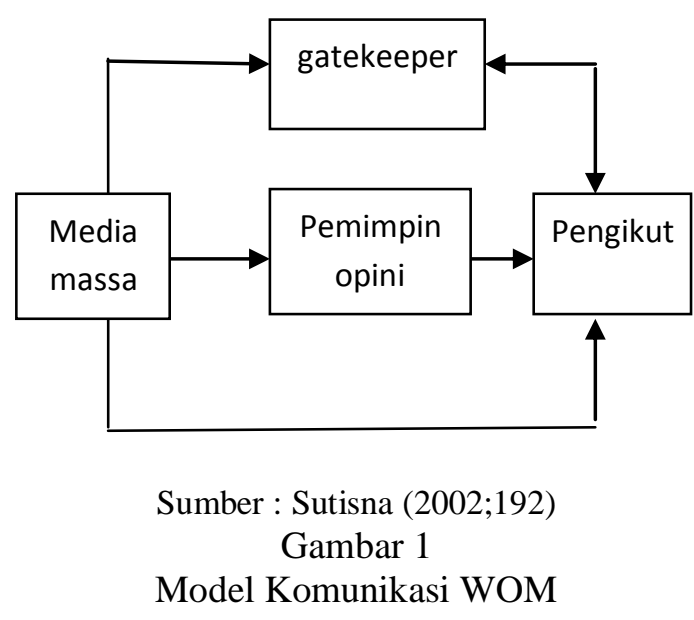


Orang-orang yang ditanya dan diminta informasinya disebut sebagai pemimpin opini (opinion leaders). Pemimpin opini merupakan orang yang sangat sering mempengaruhi sikap dan perilaku orang lain. Berdasarkan riset yang dilakukan Lazarsfed (1940), menunjukkan bahwa pengaruh langsung dari media massa terhadap pilihan pemilih sangat kecil. Bersama dengan rekannya mengemukakan dalil "Two Step Flow Communication" yang berisi pertama, mass media mempengaruhi pemuka pendapat (opinion leader), kedua, opinion leader mempengaruhi individu-individu lainnya. Hasil riset itu menunjukkan bahwa konsumen mengumpulkan informasi dari beberapa media promosi termasuk iklan dan tenaga penjual, kemudian menceritakan kepada teman-temannya. Pemasar harus lebih jeli tentang informasi yang beredar dan sedapat mungkin menyisipkan informasi tentang produknya dalam informasi yang sedang ramai dibicarakan. Kotler (2005: 117-118) menambahkan bahwa "Tantangan utama sekarang ini adalah menarik perhatian konsumen dengan cara menemukan cara baru untuk menarik perhatian dan menanamkan brand dalam benak setiap orang". Humas dan pemasaran mulut ke mulut semakin berperan dalam bauran pemasaran dalam rangka membangun dan memelihara brand.

Beberapa faktor dapat dijadikan dasar motivasi bagi konsumen untuk membicarakan mengenai produk , menurut Sutisna $(2002 ; 185)$ diantaranya adalah sebagai berikut:
1. Seseorang mungkin begitu terlibat dengan suatu produk tertentu atau aktivitas tertentu dan bermaksud membicarakan hal itu dengan orang lain, sehingga terjadi proses komunikasi wom.

2. Seseorang mungkin banyak mengetahui mengenai produk dan menggunakan percakapan sebagai cara untuk menginformasikan kepada yang lain.

3. Seseorang mungkin mengawali suatu diskusi dengan membicarakan sesuatu yang keluar dari perhatian utama diskusi.

4. WOM merupakan satu cara untuk mengurangi ketidakpastian, karena dengan bertanya kepada teman, tetangga atau keluarga, informasinya lebih dapat dipercaya, sehingga juga akan mengurangi waktu penelusuran dan evaluasi merek.

Dari penjelasan tersebut kita dapat mengambil kesimpulan bahwa karakter suka berkumpul merupakan cermin dari kekuatan pembentukan grup dan komunitas. Kekuatan komunitas ini sangat besar pengaruhnya terhadap strategi pemasaran. Salah satu strategi yang penting adalah strategi komunikasi yang menggunakan word of mouth untuk membantu penetrasi pasar dari suatu merek.

\section{Menciptakan Word Of Mouth}

Untuk mempromosikan produknya melalui word of mouth, pemasar dapat merangsang atau menciptakan komunikasi word of mouth. Contohnya seperti yang sering kita lihat di rumah makan padang, 
sering terbaca tulisan besar "Bila Anda Puas Beritahu Teman, Bila Anda Tidak Puas Beritahu Kami”. Itu mungkin suatu cara pemasar untuk merangsang terjadinya word of mouth di antara konsumennya untuk menarik calon konsumen baru sekaligus untuk menjaga supaya tidak terjadi word of mouth negatif yang malah akan menjatuhkan image produknya. Namun tidak semua produk dapat dipromosikan melaui word of mouth, setidaknya produk tersebut harus memiliki enam unsur untuk dapat menghasilkan wordof-mouth secara positif dan terus menerus:

1. Produk tersebut harus mampu membangkitkan tanggapan emosional.

2. Produk atau merek tersebut harus mampu memberikan efek sesuatu yang delight atau excitement. Berarti produk harus mampu memberikan sesuatu yang melebihi dari ekspetasi konsumen.

3. Produk tersebut harus mempunyai sesuatu yang dapat mengiklankan dirinya sendiri atau memberikan inspirasi seseorang untuk menanyakan hal tersebut.

4. Suatu produk menjadi lebih powefull bila penggunanya banyak.

5. Produk tersebut harus kompatibel dengan produk lainnya, khususnya dapat diaplikasikan di produk yang mengandalkan teknologi.

6. Pengalaman konsumen menggunakan produk pertama kali. Sekali konsumen kecewa, mereka tidak akan menggunakan produk anda lagi dan mereka akan bertindak seperti teroris.
Selain harus memiliki enam unsur di atas, terdapat beberapa metode yang dapat dipakai untuk menciptakan atau merangsang terjadunya word of mouth. Seperti yang dikemukakan Saptaningsih Sumarni (2008) : "Konsumen yang terpuaskan (harapannya akan produk/jasa itu terpenuhi), belum tentu $100 \%$ akan menceritakannya kepada orang lain. Misal ketika ia membeli/mengkonsumsi sebuah produk atau jasa, ia tidak merasakan suatu pengalaman hebat, atau kepuasan emosional yang lebih, sehingga WOM tidak akan muncul. Paling ketika ditanya oleh temannya tentang baguskah produk A? Ia akan menjawab, "Iya lumayanlah ga jelek-jelek banget kok, sesuai harganya." WOM muncul karena ditanyakan, bukan karena bangga. Oleh karena itu perlu dilakukan beberapa metode untuk merangsang terjadinya word of mouth."

Berdasarkan penelitian Diamond Management \& Technology Consultant yang dikemukakan oleh Saptaningsih Sumarni (2008) terdapat beberapa metode word of mouth antara lain:

1. Buzz marketing, menggunakan kegiatan hiburan atau berita yang bagus supaya orang membicarakan brand kita.

2. Evangelist marketing, "menanam" para penyebar berita (evangelist), pembicara atau relawan yang menjadi pemimpin dalam aktivitas penyebaran secara aktif atas nama anda.

3. Community marketing, membentuk atau mendukung ceruk komunitas (niche community) yang dengan 
senang hati membagi ketertarikan mereka terhadap brand, menyediakan alat, konten, dan informasi untuk mendukung komunitas tersebut.

4. Conversation creation, iklan yang menarik atau lucu, e-mail, hiburan untuk memulai aktivitas WOM.

5. Influencer marketing, mengidentifikasi komunitas kunci dan opinion leader yang dengan senang hati menceritakan produk dan memiliki kemampuan untuk mempengaruhi opini orang lain.

6. Cause marketing, memberikan dukungan untuk program sosial melalui pengumpulan dana untuk mendapatkan respek dan dukungan dari orang-orang yang memiliki concern yang sama dengan perusahaan.

7. Viral marketing, menciptakan pesan yang menghibur dan informatif yang didesain untuk disebarkan secara eksponensial melalui media elektronik atau email.

8. Grassroots marketing, mengatur dan memotivasi relawan untuk terlibat secara personal atau lokal.

9. Brand blogging, menciptakan blogs dan berpartisipasi dalam blogosphere, dalam semangat keterbukaan, komunikasi transparan, berbagi informasi nilai yang mungkin dibicarakan komunitas blogs.

10. Product seeding, menempatkan produk yang tepat di tangan yang tepat, pada waktu yang tepat pula, menyediakan informasi atau sample untuk individu berpengaruh.
11. Referral programs, menciptakan alat bagi pelanggan yang puas agar mereka merekomendasikan produk yang sama kepada temantemannya.

Metode tersebut harus dikelola agar aktifitas word of mouth dapat terus berjalan dengan baik dan terus berkembang. Serta pemasar dapat mengambil masukan untuk meningkatkan kualitas dan menyesuaikan produk pada kebutuhan dan keinginan pasar yang terus berkembang. Menurut Saptaningsih Sumarni (2008), Putri (2007) menjelaskan jika pelanggan puas tentunya mereka akan mempromosikan word-of-mouth. Selain berfokus kepada kepuasan pelanggan, pemasar juga dapat mengelola aktivitas word-ofmouth dengan cara-cara:

1. Conversation tracking, yaitu memonitor pembicaraan yang berkaitan dengan suatu merek, baik pembicaraan offline maupun online.

2. Menciptakan komunitas dengan ketertarikan/bidang yang sama.

3. Program brand advocacy, yaitu memilih pelanggan yang loyal untuk bertindak mewakili brand tersebut.

4. Memberikan pelayanan yang superior, sehingga menciptakan kepuasan pelanggan.

5. Blog marketing, yaitu mengelola blog perusahaan ataupun terkait dengan produk dan berhubungan dengan orang lain melalui blog.

6. Influencer marketing, yaitu mengidentifikasi siapa saja yang besar pengaruhnya dalam sebuah 
social network dan bekerjasama dengan mereka.

Word-of-mouth dapat menciptakan image negatif yang dapat melawan suatu merek. Untuk itu, pemasar dapat memanfaatkan langkahlangkah diatas untuk menyerang balik word-of-mouth yang negatif. Tetapi yang paling utama tetaplah pelayanan pelayanan yang superior, karena dari sanalah semua bermula. Pelayanan superior adalah langkah paling efektif dalam melawan word-of-mouth yang negatif. Menurut Tuhu Nugraha Dewanto (2008), mengemukakan bahwa "Menurut Sernovitz, ada lima T yang harus diperhatikan saat melakukan kampanye ini. Kelima hal tersebut adalah, Talker, Topics, Tool, Taking Part, dan Tracking:"

1. Talker adalah orang-orang yang akan menjadi perantara membicarakan produk Anda.

2. Topics ini seharusnya sesuatu yang sederhana, dan memang berasal dari produk itu sendiri.

3. Tools berbicara tentang segala perlengkapan yang seharusnya disiapkan agar memudahkan konsumen melakukan word of mouth.

4. Taking Part, menjelaskan bagaimana seharusnya Anda terlibat dalam proses ini.

5. Tracking. Dengan ini akan memudahkan Anda mengetahui siapa yang menjadi talker produk Anda, topik apa yang menjadi WOM, dan mengetahui apakah Tools yang Anda siapkan bekerja dengan baik.

\section{Word Of Mouth Negatif}

Seperti yang telah disebutkan diatas, bahwa word of mouth tidak saja memberi dampak positif tetapi juga dampak negatif, atau sering disebut dengan word of mouth negatif. Diaman menurut Saptaningsih Sumarni (2008):

"Word-of-mouth negatif adalah suatu fenomena yang paling ditakutkan perusahaan atau pengusaha. Karena seorang konsumen yang tingkat kepuasaan, terutama emosionalnya negatif, akan berbicara, bukan hanya ke orang-orang dekatnya saja. Ketidakpuasan belum tentu dari fisik sebuah produk/jasa, tapi dapat intangible seperti mungkin dari fasilitas, pelayanan dan pengalamannya ketika melakukan purchase."

Pendapat di atas dipertegas oleh pendapat Sutisna $(2002 ; 186)$ bahwa "diskusi informal diantara konsumen mengenai suatu produk dapat mengakibatkan produk tersebut hilang dari toko-toko atau penjual eceran lainnya karena tidak lagi disukai oleh konsumen. Diskusi yang negatif mengenai suatu merek produk dapat mempunyai bobot yang lebih besar bagi konsumen dari pada hal-hal yang positif." Hal tersebut diakibatkan oleh sifat manusia yang lebih senang menceritakan ketidakpuasan daripada menceritakan kepuasannya pada suatu produk. Sejalan dengan pendapat Sutisna $(2002 ; 186)$ "Banyak peneliti manyatakan bahwa jika seseorang konsumen merasa puas, maka dia hanya akan bicara kepada satu orang saja, dan sebaliknya jika tidak puas dia akan 
bicara ketidakpuasannya itu kepada sepuluh orang".

Untuk mengatasi atau mengontrol word of mouth negatif banyak perusahaan yang membuka layanan consumer service online untuk menampung ketidakpuasan, keluhan, kritik dan saran dari konsumen sebelum menyebar lebih luas, sehingga akan sulit dikontrol oleh perusahaan. Atau setidaknya perusahaan mencantumkan slogan "Bila Anda puas berutahu teman, dan bila Anda tidak puas beritahu kami”.

\section{KESIMPULAN}

Word of Mouth memiliki kekuatan tersendiri untuk menjadi strategi yang dapat diandalkan dalam proses persuasi konsumen untuk bersedia dan setia memakai produk atau jasa yang ditawarkan oleh produsen maupun penyedia jasa. Namun yang harus diingat adalah strategi ini cenderung bermanfaat untuk mengurangi rasa percaya konsumen terhadap produk dan jasa pesaing bisnis dari pada meningkatkan rasa percaya konsumen terhadp barang dan jasa yang ditawarkan. Hal ini disebabkan manusia lebih suka mendengarkan berita negatif dari pada berita positif.

\section{DAFTAR PUSTAKA}

Kasali, Renald. 2003. Manajemen Public Relations. Bandung: PT Remaja Rosdakarya.

Kasali, Renald. 1994. Manajemen Public Relations dan Konsep Aplikasinya di Indonesia. Jakarta: Grafiti.

Kotler, Philip. 1993. Manajemen Pemasaran: Analisis,
Perencanaan, Implementasi dan Pengendalian. Alih Bahasa Jaka Warsawa dan Herujati Purwoko. Jakarta: Erlangga.

Lazarsfield, Paul. The People's Choice: How The Voter Makes Up His Mind. Ohio; Evy County. 1940.

Sulaksana, Uyung. 2005. Integrated Marketing Communication. Yogyakarta: Pustaka Pelajar.

Sutisna. Komunikasi Pemasaran dan Komunikasi Konsumen. Bandung; remaja Rosdakarya. 2002

Sutisna. Manajemen Pemasaran. Bandung; Remaja Rosdakarya. 2002

Sumarmi, Saptaningsih. 2008 Fenomena Word of Mouth Marketing dalam Mempengaruhi Keputusan Konsumen diakses pad a 28 juni 2015 dari www.lipy.ac.id

Warsawa dan Herujati Purwoko. Jakarta: Erlangga.

Sulaksana, Uyung. 2005. Integrated Marketing Communication. Yogyakarta: Pustaka Pelajar.

Sutisna. Komunikasi Pemasaran dan Komunikasi Konsumen. Bandung; remaja Rosdakarya. 2002

Sutisna. Manajemen Pemasaran. Bandung; Remaja Rosdakarya. 2002

Lazarsfield, Paul. The People's Choice: How The Voter Makes Up His Mind. Ohio; Evy County. 1940

Sumarmi, Saptaningsih. 2008 Fenomena Word of Mouth Marketing dalam Mempengaruhi Keputusan Konsumen diakses pad a 28 juni 2015 dari www.lipy.ac.id

Hosianna Ayu Hidayati dkk, Faktor - faktor yang membentuk komunikasi word of mouth dan pengaruhnya terhadap keputusan pembelian (studi pada konsumen ketan legenda batu), diakses dari administrasibisnis.studentjournal.u b.ac.id/index.php/jab/article/ pada tanggal 9 Juli 2015. 


\section{UCAPAN TERIMA KASIH}

Redaksi Jurnal Humanika mengucapkan terima kasih atas partisipasi dan kesediaan Mitra Bestari untuk Volume. 15. Nomor. 1. September 2015, kepada;

Ajat Sudrajat (Universitas Negeri Yogyakarta) untuk artikel

1. "Islam Rahmah dan Wasathiyah (Paradigma Keberislaman Inklusif, Toleran dan Damai)" (Abd. Malik Usman)

2. "Etika Sosial dalam Kerukunan Umat Beragama (Studi Kasus di Desa Kotesan Kecamatan Prambanan Kabupaten Klaten Jawa Tengah)” (Andy Dermawan dan Zunly Nadia)

3. "Mencari Model Pendidikan Karakter" (Suparlan)

Suranto Aw (Universitas Negeri Yogyakarta) untuk artikel

1. "Persepsi Masyarakat Kotagede terhadap Pengunaan Media Komunikasi oleh Organisasi Forum Joglo untuk Pelestarian Budaya di Kotagede Yogyakarta” (Choirul Fajri)

2. "Implikasi Budaya Organisasi terhadap Pola Perilaku Komunikasi Kelompok Tani Sumber Rejeki” (Mariana Ulfah dan Siti Chotijah)

3. "Model Komunikasi "Wom” sebagai Strategi Pemasaran Efektif” (Dani Fadillah)

Yayan Suryana (Universitas Islam Negeri Sunan Kalijaga Yogyakarta) untuk artikel

1. "The Dialectics of Javanese and Islamic Cultures: an Introduction to Kuntowijoyo’s Thought” (Pradana Boy ZTF) 